\title{
Timing of Atlantic cod Gadus morhua seasonal migrations in relation to serum levels of gonadal and thyroidal hormones
}

\author{
Luc A. Comeau ${ }^{1, *}$, Steven E. Campana ${ }^{2}$, Ghislain A. Chouinard ${ }^{3}$, \\ J. Mark Hanson ${ }^{3}$ \\ ${ }^{1}$ Department of Biology, Dalhousie University, Halifax, Nova Scotia B3H 4J1, Canada \\ ${ }^{2}$ Department of Fisheries and Oceans, Marine Fish Division, Bedford Institute of Oceanography, PO Box 1006, Dartmouth, \\ Nova Scotia B2Y 4A2, Canada \\ ${ }^{3}$ Department of Fisheries and Oceans, Gulf Fisheries Centre, PO Box 5030, Moncton, New Brunswick E1C 9B6, Canada
}

\begin{abstract}
Serum testosterone, estradiol-17 $\beta\left(\mathrm{E}_{2}\right)$, L-thyroxine $\left(\mathrm{T}_{4}\right), 3,5,3$ '-triiodo-L-thyronine $\left(\mathrm{T}_{3}\right)$, and free (protein-unbound) $\mathrm{T}_{3}$ concentrations were examined in relation to the extensive (up to $650 \mathrm{~km}$ ) seasonal migrations undertaken by southern Gulf of St. Lawrence cod Gadus morhua L.. Testosterone levels were low as the stock moved out of the Gulf of St. Lawrence in autumn, and increased only during the final stages of the return migration in spring. $\mathrm{E}_{2}$ in females peaked near the onset of the spring migration, and remained elevated until this migration was completed in early summer. However, we suggest that the changes in $\mathrm{E}_{2}$ levels are functionally tied with egg development and not with spring migratory behaviour. Free $\mathrm{T}_{3}$ showed no consistent pattern in relation to seasonal migrations, whereas $\mathrm{T}_{4}$ and $\mathrm{T}_{3}$ levels increased at the start of the autumn migration. We conclude that thyroid hormones may facilitate the onset of the autumn migration by enhancing metabolism, sensory physiology and swimming capacity.
\end{abstract}

KEY WORDS: Gadus morhua $\cdot$ Cod $\cdot$ Migration $\cdot$ Gonadal hormones $\cdot$ Thyroid hormones $\cdot$ Equinox · Gulf of St. Lawrence

Resale or republication not permitted without written consent of the publisher

\section{INTRODUCTION}

Atlantic cod Gadus morhua L. populations generally move from coastal to offshore areas in autumn, overwinter in deep slope waters, and return to more inshore areas in the spring. Such orderly and extended (up to $1000 \mathrm{~km}$ : Woodhead 1975) seasonal migrations are now recognized for many of the world's most commercially-important cod populations, such as the Arcto-Norwegian and Barents Sea cod (Harden Jones 1968, Woodhead 1975), West Greenland cod (Harden

*E-mail: luccomeau@hotmail.com
Jones 1968, Hovgård \& Christensen 1990), Newfoundland and Labrador cod (Templeman 1979, Lear \& Green 1984), eastern Scotian Shelf cod (McKenzie 1956, Scott 1988), northern Gulf of St. Lawrence cod (Templeman 1979, Moguedet 1994, Taggart et al. 1995), and southern Gulf of St. Lawrence cod (Jean 1964, Paloheimo \& Kohler 1968).

While migratory patterns are well documented, very little is understood about the underlying triggering mechanism. Woodhead (1975) suggested that changing levels of circulating thyroid hormones in the bloodstream trigger migratory behaviour, since these hormones increase swimming speeds in both laboratory (Woodhead 1970, Castonguay \& Cyr 1998) and field- 


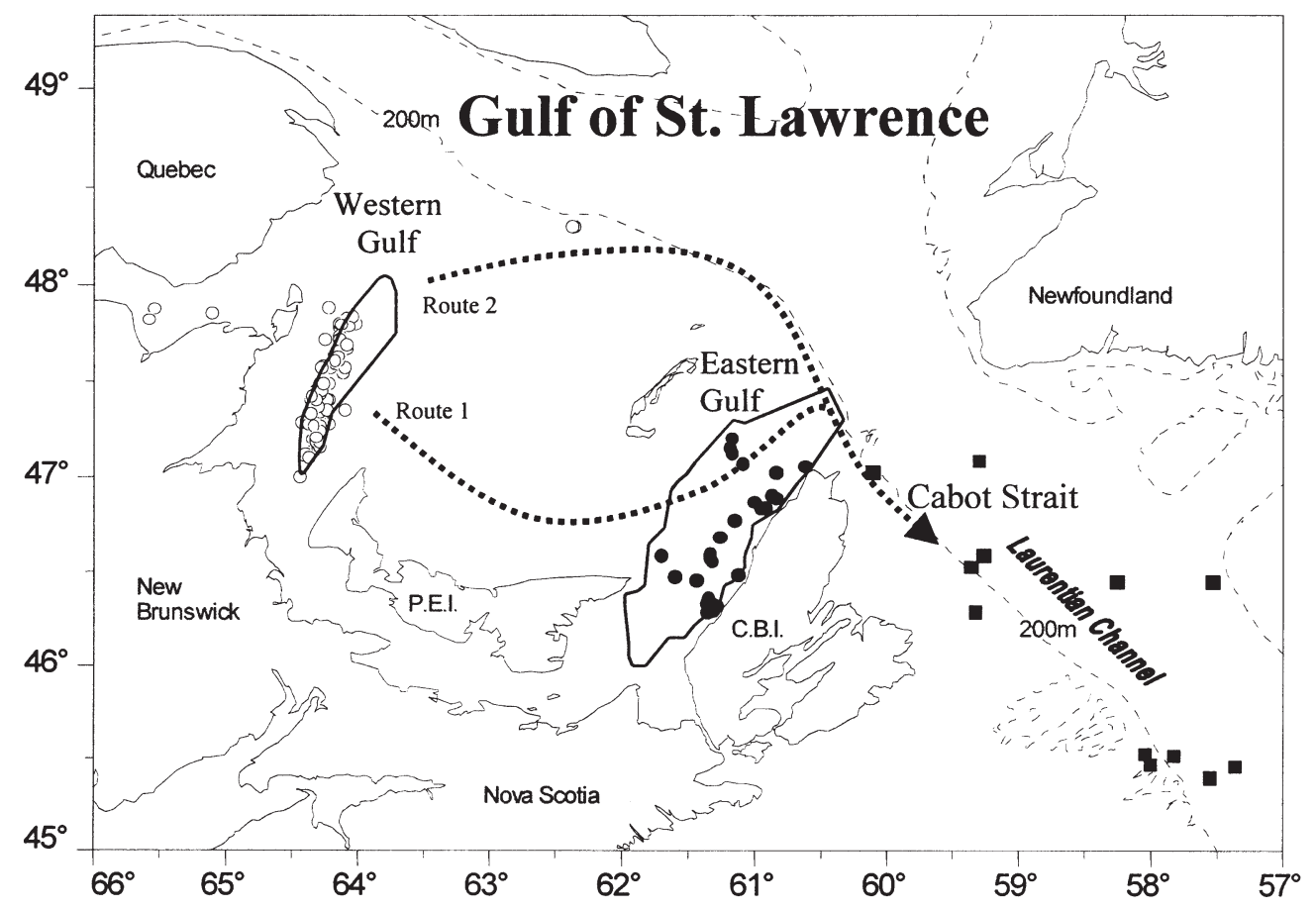

Fig. 1. Gadus morhua. Capture locations of cod from 1994 to 1997, and the 2 most likely migration routes (Sinclair \& Currie 1994, G. A. Chouinard unpubl. data) between the southern Gulf of St. Lawrence (summer) and the Cabot Strait (winter) grounds. (Bold delimitation lines show zones inside which sentinel vessels operated.) Symbols indicate sampling stations in western Gulf area (०), eastern area $(\bullet)$ and Cabot Strait region $(\mathbf{\bullet})$. O symbols outside western Gulf represent sites visited in August and September 1994, prior to the beginning of sentinel surveys

released (Woodhead 1975) cod. Similarly, gonadal hormones may also trigger migration because of the common linkage of migration and reproduction, and because testosterone enhances locomotor activity in teleosts (Hoar et al. 1952, 1955, Baggerman 1963, 1966). Until the present study, however, the natural changes in the levels of endocrine hormones had not been examined in relation to the extensive migrations of cod.

Our goal was to determine whether thyroid or reproductive hormones were correlated with the seasonal migrations of southern Gulf of St. Lawrence cod (Fig. 1). Scientific surveys have identified the western Gulf as being a major summer ground for the stock (summarized by Swain 1999). In autumn, however, southern Gulf cod migrate distances up to $650 \mathrm{~km}$ (Hanson 1996) to overwinter in the Cabot Strait along the southern edge of the Laurentian Channel (Jean 1964, Paloheimo \& Kohler 1968, Halliday \& Pinhorn 1982, Campana et al. 1999). In spring, the cod migrate back into the southern Gulf, thus completing the annual migration cycle. We monitored on a frequent basis the circulating levels of testosterone, estradiol$17 \beta\left(\mathrm{E}_{2}\right)$, L-thyroxine $\left(\mathrm{T}_{4}\right), 3,5,3^{\prime}$-triiodo-L-thyronine $\left(T_{3}\right)$, and free (protein-unbound) $T_{3}$ in relation to the onset of seasonal migrations.

\section{MATERIALS AND METHODS}

We investigated the timing of the autumn migration of Gadus morhua L. using sentinel survey data. Sentinel surveys consist of periodic sampling excursions on traditional fishing grounds following a scientific protocol. Two sentinel seiners carried out trips into the western Gulf from October to November in 1994, and from July to October in 1995, 1996 and 1997. During each trip, about 10 standardized sets were made at randomly chosen locations within the western Gulf. We used the precipitous decline in catch rate as an indicator of the timing of departure of the cod. We also examined catch rates from sentinel vessel operations in the eastern Gulf (1996 to 1997) to identify arrival of fish from the western portion of the stock. Data from Sinclair \& Currie (1994) were used to document spring migrations.

We collected samples in the Cabot Strait area during the winter and spring, and in the southern Gulf of St. Lawrence during the summer and autumn. Winter and spring samples were collected every second month in 1996 and 1997, whereas summer and autumn samples were taken on a near-weekly basis between 1994 and 1997. The number of fish collected during each trip ranged from 7 to $106($ mean $=30)$ and both sexes were 
generally well represented. The mean fork length (FL) of cod in samples varied from 46 to $60 \mathrm{~cm}$, except for the August 1994 sample (mean FL $=67 \mathrm{~cm}$ ).

Most samples were captured using mobile gear vessels that carried out $60 \mathrm{~min}$ sets. In October and November 1996, however, $43 \%$ of the eastern Gulf samples were collected using baited longlines. The soaking time of longlines ranged from 4 to $24 \mathrm{~h}$. No effects of gear-type on the concentrations of hormones were found (Mann-Whitney $U$-test, $\mathrm{p}<0.22$ ) when comparing samples collected with mobile and longline gear in the same area on the same day. Blood samples were retrieved within about $20 \mathrm{~min}$ after the fish were boated. The aorta was cut and blood was allowed to flow directly into $7 \mathrm{ml}$ Vacutainer vials. The vials were capped and refrigerated for 12 to $24 \mathrm{~h}$. The serum fraction was then transferred into $2.5 \mathrm{ml}$ cryovial tubes and stored at $-72^{\circ} \mathrm{C}$ until analyzed. Cod were kept on ice and dissected within $48 \mathrm{~h}$ or frozen at $-20^{\circ} \mathrm{C}$ and dissected after having been partially thawed. We determined the gonadosomatic index (GSI) as 100 ( the wet weight of the gonads divided by the wet weight of the carcass (total body weight minus combined weight of liver, gonads, and stomach) (Schwalme \& Chouinard 1999).

We measured $\mathrm{T}_{4}$ and $\mathrm{T}_{3}$ on 1456 samples using a combined radioimmunoassay (RIA) technique (Omeljianuk et al. 1984) and the reagents employed by Cyr et al. (1998). Details of the procedures are also given in Comeau et al. (2000). We measured free $\mathrm{T}_{3}$ levels on 638 samples using G-25 Sephadex columns (Eales \& Shostak 1985). In this approach, the free fraction is not quantified directly, but computed from the radioactivity measured in the eluted protein-bound fraction. Because most of the circulating $T_{3}$ is naturally bound to plasma proteins, sample dilution is necessary to detect small variations in the free $T_{3}$ fraction. For cod, linearity between the percentage of ${ }^{125} \mathrm{I}_{-} \mathrm{T}_{3}$ bound to serum proteins (eluate) and the dilution of pooled serum samples was maintained down to a dilution factor of about 1:20 (serum:phosphate buffer). Therefore, all samples were diluted 1:10, which was well within the linearity limits of the dilution curve. In the first step of the procedure, $100 \mu \mathrm{l}$ (ca 10000 counts) of ${ }^{125} \mathrm{I}_{-} \mathrm{T}_{3}$ tracer was pipetted onto G-25 Sephadex columns previously equilibrated in $0.1 \mathrm{NaOH}$. Free iodide contamination $\left({ }^{125} \mathrm{I}^{-}\right)$was removed by introducing $3 \mathrm{ml}$ of phosphate buffer into the columns. The contamination was measured and subtracted from the total counts added to the columns in Step 1. One ml of diluted serum was added to each column. Shortly after the serum had drained into the Sephadex, $3 \mathrm{ml}$ of phosphate buffer was pipetted into the columns and the eluate containing the protein-bound ${ }^{125} \mathrm{I}_{-} \mathrm{T}_{3}$ was counted. Free $\mathrm{T}_{3}$ percentage values were computed as in Eales \& Shostak (1985), and then converted into concentration values using $T_{3}$ results from the combined $\mathrm{T}_{4}-\mathrm{T}_{3}$ RIA (i.e. total $\mathrm{T}_{3}$ ) and the following formula:

free $\mathrm{T}_{3}\left(\mathrm{ng} \mathrm{ml}^{-1}\right)=$ total $\mathrm{T}_{3}\left(\mathrm{ng} \mathrm{ml}^{-1}\right) \times$ free $\mathrm{T}_{3}(\%) \times 10^{-2}$

Gonadal hormones were measured using commercial Coat-A-Count ${ }^{\circledR}$ RIA kits (Diagnostic Products Corporation, Los Angeles, CA, USA). A total of 1140 samples (436 males, 704 females) were processed in duplicate for the measurement of $E_{2}$ levels. A similar number of samples (576 males, 548 females) were analysed, also in duplicate, for testosterone levels.

For all RIA analyses, radioactivity was measured using a Beckman Gamma 5500 Counting System. The dilution of cod serum samples yielded hormone levels close to the predicted values, and the dilution curves of samples were parallel to the dilution curves of standards. Intra- and interassay coefficients of variation were less than $10 \%$.

\section{RESULTS}

Because few Gadus morhua samples were collected during the spring migration period, we decided to pool the 1996 and 1997 data in order to present the 2 sexes separately (Fig. 2). In spring, the mean (1996 and 1997) GSI values were either increasing (females) or had already reached their maximum values (males) by March (Fig. 2A). However, despite obvious gonad development, testosterone levels remained relatively low in both sexes until June, at which time levels clearly peaked (Fig. 2B). In contrast, $\mathrm{E}_{2}$ in females reached and persisted at maximal levels from March to June (Fig. 2C). Also, the $E_{2} /$ testosterone ratio clearly surpassed the 1.0 mark in March (Fig. 2D), indicating that $\mathrm{E}_{2}$ was more concentrated than testosterone. $\mathrm{E}_{2}$ levels in males were extremely low $\left(<0.1 \mathrm{ng} \mathrm{m}^{-1}\right)$ throughout the year, and are not shown graphically. Thyroid hormone levels were either low or declining when cod migrated into the western Gulf during the spring of 1996 and 1997.

From 1994 to 1997, there was a prominent rise in sentinel catch rates in the western Gulf in early October, followed by sharp declines to null values in late October (Fig. 3A). The timing of the autumn peaks ranged from October 2 to 13 (mean = October 8), and thus was relatively constant from year to year $(\mathrm{SE}=2$ d). Major peaks and steep declines in catch rates were also detected in the eastern Gulf (Fig. 3B). In this area, the peaks occurred in late October (mean = October $22, \mathrm{SE}=1 \mathrm{~d}$ ), indicating the arrival of fish from the western Gulf.

Testosterone levels usually remained low in males as they departed the western Gulf in 1995, 1996 and 1997 



Fig. 2. Gadus morhua. Seasonal changes in the gonadosomatic index (GSI), testosterone, estradiol-17 $\beta$, and estradiol$17 \beta /$ testosterone ratio in male $(\bullet)$ and female $(\square)$ cod. Results from 1996 and 1997 were pooled to increase sample sizes. Data points represent monthly means $( \pm$ SE). SM horizontal bar indicates the approximate timing and duration of the spring migration as inferred from Sinclair \& Currie (1994) and July sentinel data

(Fig. 4A). $E_{2}$ levels in females were also generally low at this time (Fig. 4B), and no consistent pattern emerged from the free $\mathrm{T}_{3}$ series (Fig. 4C). However, serum $\mathrm{T}_{4}$ levels peaked about $15 \mathrm{~d}$ before the maximum catch rates were recorded (Fig. 5). The mean timing of the $\mathrm{T}_{4}$ peaks between 1994 and 1997 was September 23 (autumn equinox) with very little interannual variability $(\mathrm{SE}=1 \mathrm{~d})$. Consequently, we decided to group the thyroid data into 3 periods: summer residency, near-autumn equinox, and autumn migration. Mean levels of thyroid hormones near the autumn equinox were significantly higher (2 to $3 \mathrm{ng}$ $\mathrm{ml}^{-1}$ ) than those during the summer residency period $\left(\mathrm{T}_{4}\right.$, Fig. 6A) and 4 to $5 \mathrm{ng} \mathrm{ml}^{-1}$ ( $\mathrm{T}_{3}$, Fig. 6B). In percentage terms, the mean equinoxial increases were $173 \%$ $\left(\mathrm{T}_{4}\right)$ and $26 \%\left(\mathrm{~T}_{3}\right)$. A comparatively small number of samples collected near the equinox in 1995 (16 compared to 29-37 fish in other years) might have been responsible for the lack of statistical significance in that year.

While the levels of both thyroid hormones increased near the autumn equinox, $\mathrm{T}_{4}$ showed greater year-toyear variability than $T_{3}$ : the equinoxial $T_{4}$ means differed between the investigation years $(p<0.001$, Krustal-Wallis test) whereas the equinoxial $\mathrm{T}_{3}$ means did not differ ( $p<0.21$, Krustal-Wallis test). Also, for
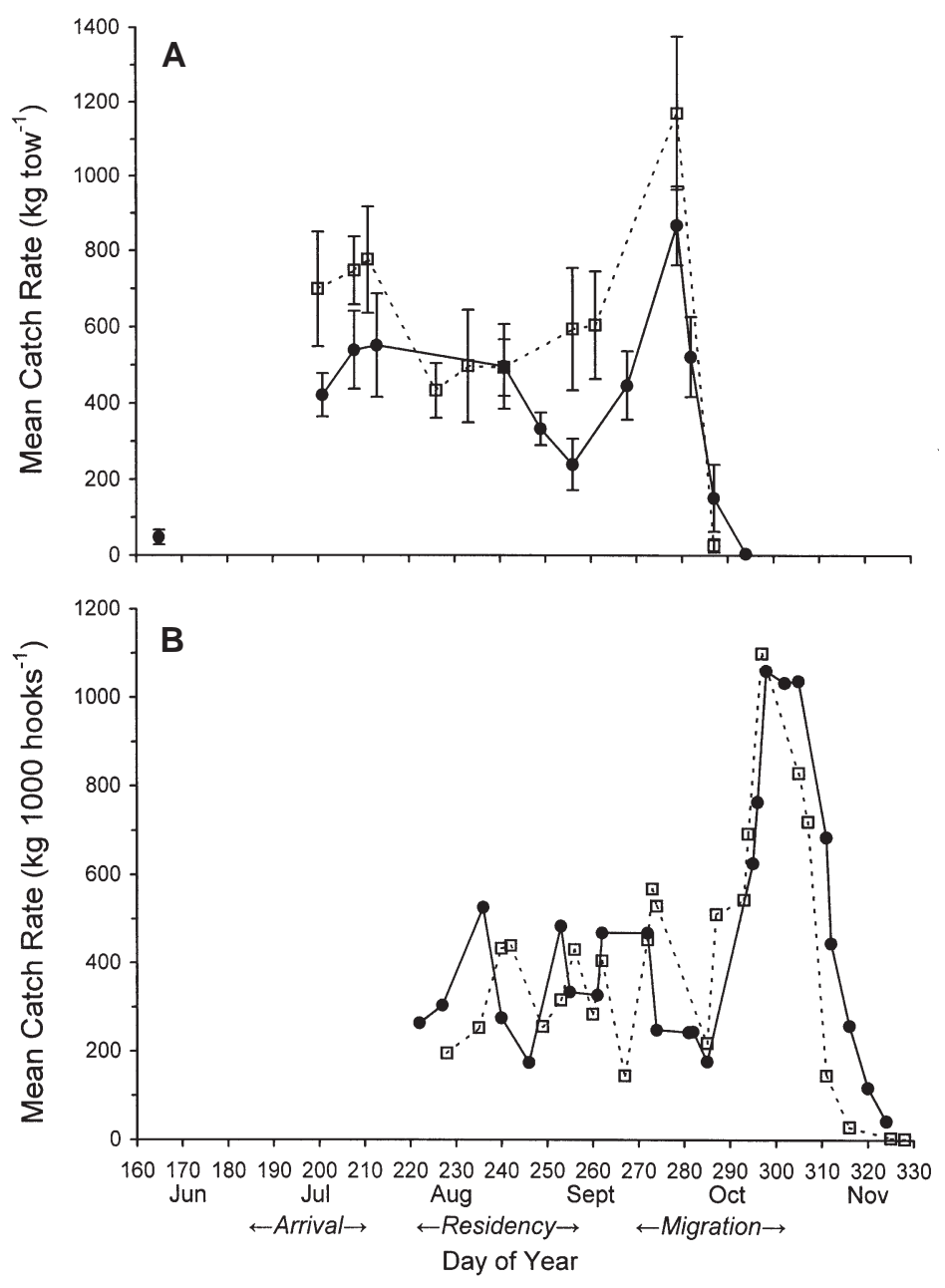

Fig. 3. Gadus morhua. Changes in catch rates of cod during sentinel expeditions in 1996. In each graph, $\bullet$ and $\square$ symbols represent different survey vessels. In the western Gulf (A), data points are means $( \pm \mathrm{SE})$ of 6 to 8 tows, except for June where only 3 tows were carried out during a separate research expedition. In the eastern Gulf (B), data points are catches per 1000 hooks (longline) 

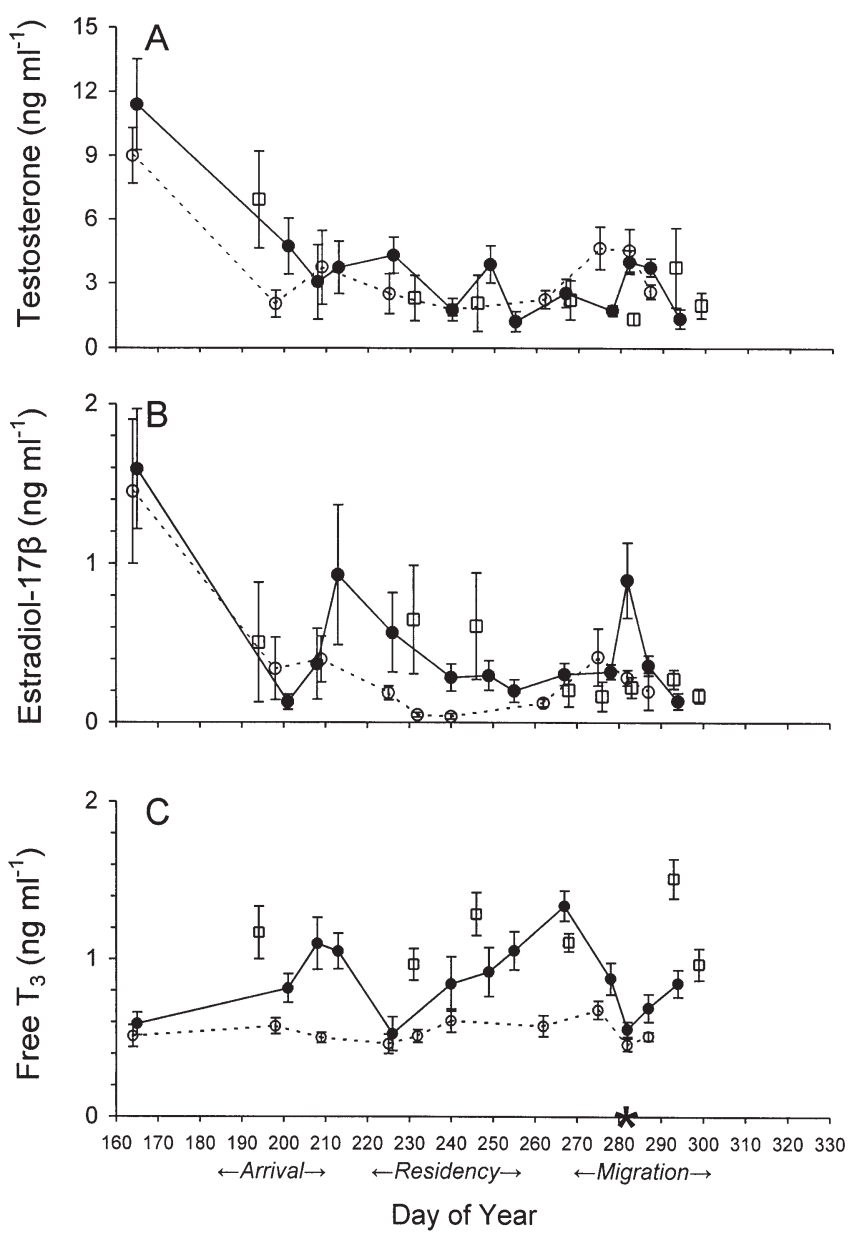

Fig. 4. Gadus morhua. Summer and autumn testosterone (males), estradiol-17 $\beta$ (females), and free $\mathrm{T}_{3}$ (both sexes) levels in western Gulf cod in 1995 (), 1996 (•), and 1997 (०). Data points represent expedition means $( \pm$ SE). Data from 1994 have been omitted because of low sample sizes. *: mean date (October 8, Day 281) when sentinel catch rates peaked before declining to null values

any given year, the $\mathrm{T}_{4}$ levels recorded near the autumn equinox were highly variable from one individual to another, with the sample coefficient of variation (CV) ranging from 80 to $146 \%$. In comparison, the sample $\mathrm{CV}$ for $\mathrm{T}_{3}$ ranged from 26 to $34 \%$. After the equinox, as cod quickly moved out of the western Gulf (Autumn Migration I in Fig. 6A,B), the mean $\mathrm{T}_{4}$ levels fell sharply but the mean $\mathrm{T}_{3}$ levels remained elevated.

In the eastern Gulf, the concentrations of thyroid hormones also increased near the autumn equinox (Fig. 6C, D). At this time, both $\mathrm{T}_{4}$ and $\mathrm{T}_{3}$ means were similar to those recorded in the western Gulf $(p>0.05$, Mann-Whitney 2-sample test applied to 1996 and 1997 series separately). Also, as in the case of the western Gulf, the variation between individuals during the equinoxial period was greater for $\mathrm{T}_{4}(\mathrm{CV}=124$ to
$135 \%)$ than for $\mathrm{T}_{3}(\mathrm{CV}=40$ to $49 \%)$. The levels of thyroid hormones remained elevated after the equinox (Autumn Migration II in Fig. 6C, D), as western Gulf cod transited through the eastern Gulf.

\section{DISCUSSION}

A key assumption of this study is that the measured hormone levels in Gadus morhua were not significantly distorted by capture stress. It appears that capture stress has a minimal effect on the circulating levels of both $\mathrm{T}_{4}$ and $\mathrm{T}_{3}$ (see Comeau et al. 2000). Capture stress, however, is known to reduce the levels of gonadal hormones in various fishes (Pickering et al. 1987, Pankhurst \& Dedual 1994, Jardine et al. 1996, Clearwater \& Pankhurst 1997, Morehead 1998). Yet we note that testosterone levels in field-collected cod (this study) were generally higher than those reported for laboratory-held cod (Cyr et al. 1998). For cod, it may be that confinement stress (e.g., Pickering et al. 1987, Jardine et al. 1996, Clearwater \& Pankhurst 1997, More-

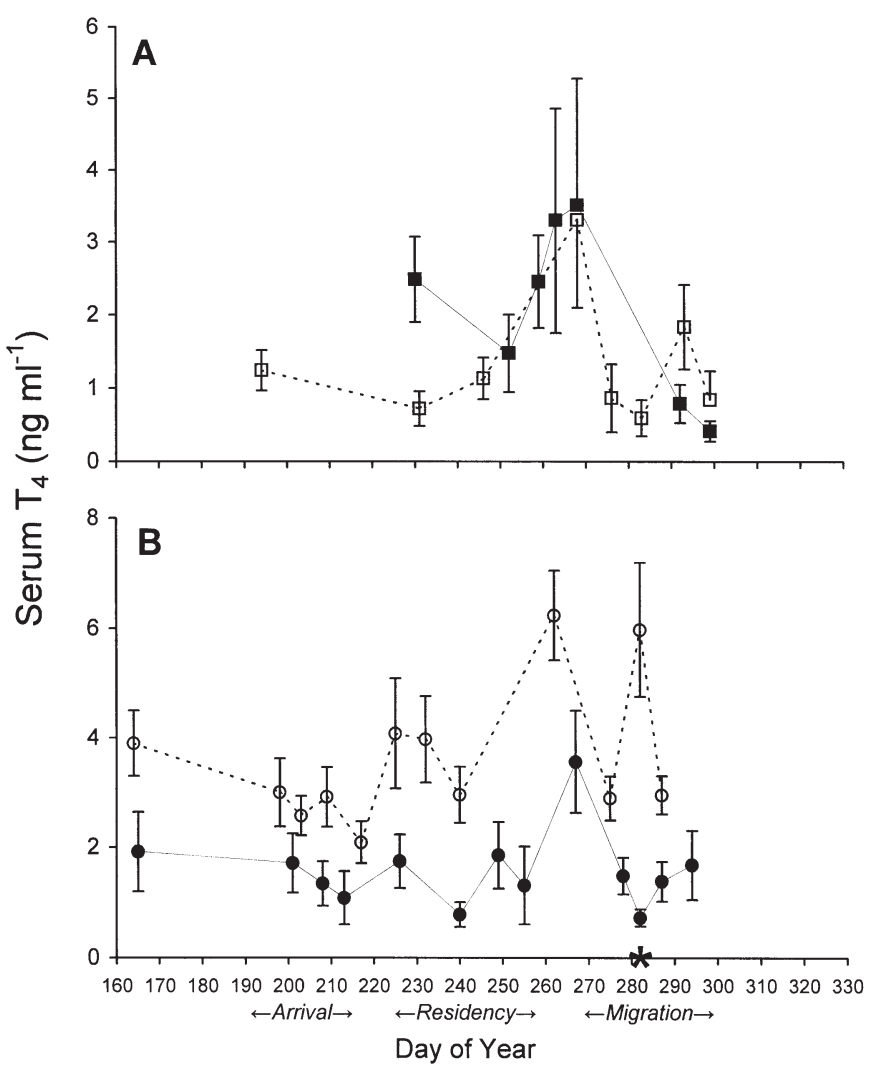

Fig. 5. Summer and autumn $\mathrm{T}_{4}$ levels in western Gulf cod in $1994(\square)$ and 1995 (ㅁ) (A), and in 1996 (•) and 1997 (O) (B). Data points represent expedition means $( \pm \mathrm{SE})$. *: mean date (October 8, Day 281) when the sentinel catch rates peaked before declining to null values. September 23 corresponds to Day 266 

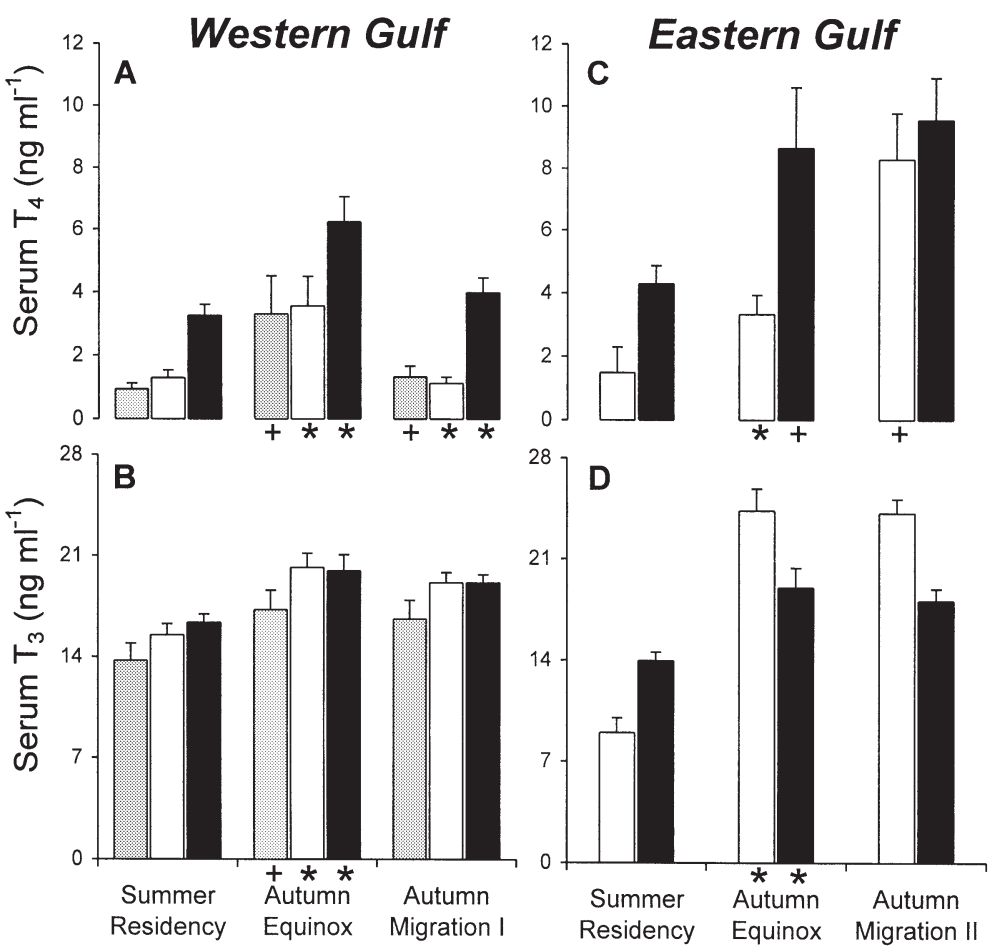

Fig. 6. Mean $( \pm \mathrm{SE}) \mathrm{T}_{4}$ and $\mathrm{T}_{3}$ levels during the summer residency, equinoxial, and migration periods in 1995 (grey bars), 1996 (open bars), and 1997 (black bars). Data from 1994 have been omitted because of low sample sizes. Summer Residency: measurements between June and the cruise closest to the autumn equinox; Autumn Equinox: cruise closest (within $7 \mathrm{~d}$ ) to the autumn equinox; Autumn Migration I: start of the migration in the western Gulf; Autumn Migration II: period when cod transited through the eastern Gulf. *: significant ( $<<0.01$, Mann-Whitney 2-sample test) difference between 2 consecutive periods; + : significance level between 0.05 and 0.10 (Mann-Whitney 2-sample test)

head 1998, Haddy \& Pankhurst 1999) has a greater impact on gonadal hormones than capture stress. Also, gonadal hormones in our study co-varied with the GSI in a manner consistent with other reports involving marine demersal fishes (Campbell et al. 1976, Wingfield \& Grimm 1977, Johnson et al. 1991, Harmin et al. 1995, Cyr et al. 1998). Therefore, we suggest that the hormone profiles in this study reflect natural changes.

We found that testosterone cycling in cod was not related to the onset of seasonal migrations. Circulating testosterone levels remained low in both males and females as they departed from the western Gulf in autumn. It appears that testosterone cycling in cod is more closely associated with the latter phases of gonad development, and most probably with spermiation as in the case of various other fishes (Liley \& Stacey 1983), than with migratory behaviour. Our observations concur with analyses of Barents Sea cod-testis tissue that showed little histological signs of secretory activity at the beginning of a spawning migration (Woodhead \&
Woodhead 1965, Woodhead 1975). Thus, it seems unlikely that male androgens, or testosterone at least, are implicated in the mechanism cueing the seasonal migrations of cod.

Unlike testosterone, $E_{2}$ increased to maximal levels in March, and remained elevated until June when the spring migration was for the most part completed. Although this profile raises the possibility that $E_{2}$ was concerned with migratory behaviour, it remains unclear as to how exactly the hormone could have cued migration. Unlike androgenic steroids, $\mathrm{E}_{2}$ has no documented influence on swimming activity. One synthetic oestrogen, stilboestrol, increased swimming speeds in goldfish, but its effects were always less pronounced than the effects of treatments with male sex hormones (Hoar et al. 1955). We found $\mathrm{E}_{2}$ levels negligible in the male, which implies that males do not undergo endocrinological changes favouring migration, but rather that they follow females on their migratory journey. In addition, the annual rise in $\mathrm{E}_{2}$ levels might not be synchronized with spring migratory behaviour in other cod populations. For example, unlike southern Gulf of St. Lawrence cod, Barents Sea cod and northern cod undertake their spring migrations as recently spent fish (Lear \& Green 1984, Rose 1993, Wroblewski et al. 1995, Ponomarenko 1996). While endocrine hormones were not reported for these populations, $\mathrm{E}_{2}$ in externally fertilizing teleosts usually reaches maximal concentrations during late ovarian development, declines substantially at the time of spawning, and remains low for a considerable amount of time after spawning (Fostier et al. 1983, Liley \& Stacey 1983, Methven et al. 1992, Harmin et al. 1995, this study). It seems reasonable to assume that $E_{2}$ levels are very low in (spent) Barents Sea cod and northern cod when they engage in spring migration; consequently, a functional link between $\mathrm{E}_{2}$ and migratory behaviour is very doubtful for cod.

In autumn, $\mathrm{T}_{4}$ levels in western Gulf cod invariably peaked close to the autumn equinox (September 23, 1994 to 1997), with the mean timing of the $\mathrm{T}_{4}$ peaks being September $23(\mathrm{SE}=1 \mathrm{~d})$. Equinoxial $\mathrm{T}_{4}$ surges were also detected in fish from the eastern Gulf, suggesting that the thyroidal event was widespread. These results imply relative daylight/night-time hours as a key signal for enhancing thyroid function in autumn. Woodhead \& Woodhead (1965) reached a 
similar conclusion for Barents Sea cod based on thyroid follicular cell height.

Our data also show a post-equinoxial decrease of $\mathrm{T}_{4}$ levels in western Gulf cod. It seems unlikely that the lowering of $T_{4}$ was caused by reduced $T_{4}$ release from the thyroid, as the thyroid function in cod increases through the autumn (Woodhead 1959, Comeau et al. 2000). Alternatively, it is possible that the postequinoxial lowering of $\mathrm{T}_{4}$ was brought about by differential migration rates. More precisely, high $\mathrm{T}_{4}$ individuals might have moved out of the Gulf faster than their low $\mathrm{T}_{4}$ counterparts, leading us to sample an increased proportion of low $\mathrm{T}_{4}$ individuals in the western Gulf as the autumn migration progressed eastward. We base this interpretation on previous work showing that $T_{4}$ increased swimming speeds in laboratory cod (Woodhead 1970, Castonguay \& Cyr 1998) and ground speeds in wild cod (Woodhead 1975). In the open-sea experiment, cod implanted subdermally with a $\mathrm{T}_{4}$ pellet reached the overwintering area significantly faster than the control individuals (Woodhead 1975). The peaks in sentinel catch rates in early October (mean = October 8, 1994 to 1997), and the subsequent declines to null values within days, are consistent with the idea that migratory restlessness is initiated close to the equinox. It is likely that the peak catch rates reflected a migration well under way, and not the onset of migratory behaviour per se. The reason is that adult cod were probably dispersed throughout the summer feeding area when they sensed the appropriate cue(s) to start migrating, and that a certain amount of time was required before they could join and form large aggregations (see Rose 1993) that ultimately influenced catch data. In brief, the post-equinoxial lowering of $\mathrm{T}_{4}$ may be viewed as an endocrine signature marking the onset of migration (September 23).

Woodhead (1959, 1975) suggested that enhanced thyroid status might motivate Barents Sea cod to turn and swim against the prevailing Norwegian current. For southern Gulf of St. Lawrence cod, however, thyroid hormone levels during the upstream migration (spring) were either equal or lower than those recorded during the downstream migration (autumn). We also found no evidence that cod migrations were cued to a specific thyroid activity level. As cod initiated migration in the western Gulf, $\mathrm{T}_{4}$ levels were highly variable amongst individuals, with sample CVs ranging from 80 to $146 \%$. It could be that individuals have different behavioural thresholds to $\mathrm{T}_{4}$. This however seems unlikely, as the mean $\mathrm{T}_{4}$ levels at the onset of migration (equinox) differed significantly across years, suggesting that the mean endocrinological threshold for reactivity would somehow vary from one year to the next. Nevertheless, our data showed that migratory behaviour was triggered after the mean concentration of circulating $\mathrm{T}_{4}$ had reached 2 to $3 \mathrm{ng} \mathrm{ml}^{-1}$ above the summer residency baseline. High $\mathrm{T}_{4}$ secretion at the autumn equinox may ensure migratory readiness by enhancing both sensory physiology (Hoar et al. 1955) and motor capacity (Woodhead 1970, Castonguay \& Cyr 1998). The equinoxial $T_{4}$ event coupled to the year-to-year consistency in migration timing identifies photoperiod as a likely external cue.

Mean $\mathrm{T}_{3}$ levels increased by 4 to $5 \mathrm{ng} \mathrm{ml}^{-1}$ at the onset of migration (equinox) and remained elevated throughout the migration. $T_{3}$ might have facilitated the autumn migration by having a generalized excitatory effect upon metabolism because it binds to (putative) nuclear receptor sites with greater affinity than $\mathrm{T}_{4}$ (Eales \& Brown 1993, Cyr \& Eales 1996). However, free $T_{3}$, which is the form that can potentially interact with nuclear receptor sites, showed no recurring pattern in relation to migration. It is possible that the lack of free $\mathrm{T}_{3}$ pattern was attributable to the hormone being metabolised as quickly as it was being released from plasma binding proteins.

In summary, major endocrine changes occurred in the Atlantic cod as it migrated seasonally. Serum $\mathrm{E}_{2}$ levels in females peaked in early spring and declined only after the cod had reached its spawning grounds. In contrast, the course of thyroid hormones was concurrent with the autumn migration, with $\mathrm{T}_{4}$ and $\mathrm{T}_{3}$ levels increasing shortly before the onset of the autumn migration was apparent from catch-rate data. We suggest that the changes in $E_{2}$ levels were functionally tied with egg development and not with spring migratory behaviour, and that thyroid hormones exerted physiological effects favouring the onset of the autumn migration. The year-to-year consistency in the timing of migration pointed to photoperiod as a likely external trigger. The indications of possible links between photoperiod, thyroid hormones, and migratory behaviour should be followed up by experimental studies.

Acknowledgements. We sincerely wish to thank all the staff at Biorex Inc. (Caraquet, New Brunswick) for their technical assistance throughout the duration of this study. We are particularly indebted to the coordinating efforts of Ola Benoit, and also to the many fisheries observers who provided field assistance on a regular basis on the sentinel surveys: Berry Aucoin, Sean Boucher, Brian Branch, Conrad Doiron, Serge Godin, Brian Harper, and Gilles Vienneau. The skippers of the 'Wayne \& Randy' (Paul-Hédard Haché), the 'Martin Bruno' (Félix Paulin), the 'Mylène H.' (Pierre Haché) and their crews kindly collaborated with the various sampling activities. The Marine Fish Division and its staff at the Bedford Institute of Oceanography (Dartmouth, Nova Scotia) provided valuable materials and facilities to L.A.C. Peter Comeau, Paul Fanning, and Bill MacEachern from the Marine Fish Division also helped with the collection of data at sea. Daniel Cyr of the Institut National de la Recherche Scientifique-Santé (Pointe-Claire, Québec) provided valued advice regarding RIA procedures. Paryse Cormier, John Smith, and Brian Irwin 
of the Department of Fisheries and Oceans kindly made available their laboratories for the isotopic work. We are also grateful to Martin Castonguay from the Institut-MauriceLamontagne (Mont-Joli, Québec) for critically reading an early draft of the manuscript.

\section{LITERATURE CITED}

Baggerman B (1963) Effects of castration in different phases of the reproductive season on breeding behavior of the male stickleback. Gen Comp Endocrinol 3: p 683

Baggerman B (1966) On the endocrine control of the reproductive behaviour in the male three-spined stickleback (Gasterosteus aculeatus L.). Hughes GM (ed) Nervous and hormonal mechanisms of integration. Vol. 20. Cambridge University Press, Cambridge, p 427-456

Campana SE, Chouinard GA, Hanson JM, Fréchet A (1999) Mixing and migration of overwintering Atlantic cod (Gadus morhua) stocks near the mouth of the Gulf of St. Lawrence. Can J Fish Aquat Sci 56:1873-1881

Campbell CM, Walsh JM, Idler DR (1976) Steroids in the plasma of the winter flounder (Pseudopleuronectes americanus Walbaum). A seasonal study and investigation of steriod involvement in oocyte maturation. Gen Comp Endocrinol 29:14-20

Castonguay M, Cyr DG (1998) Effects of temperature on spontaneous and thyroxine-stimulated locomotor activity of Atlantic cod. J Fish Biol 53:303-313

Clearwater SJ, Pankhurst NW (1997) The response to capture and confinement stress of plasma cortisol, plasma sex steroids and vitellogenic oocytes in the marine teleost, red gurnard. J Fish Biol 50:429-441

Comeau LA, Campana SE, Hanson JM, Chouinard GA (2000) Seasonal changes of thyroid hormones in field-collected Atlantic cod in relation to condition indices, water temperature, and photoperiod. J Fish Biol 57:571-588

Cyr DG, Eales JG (1996) Interrelationships between thyroidal and reproductive endocrine systems in fish. Rev Fish Biol Fish 6:165-200

Cyr DG, Idler DR, Audet C, McLeese JM, Eales JG (1998) Effects of long-term temperature acclimation on thyroid hormones deiodinase function, plasma thyroid hormone levels, growth, and reproductive status of male Atlantic cod, Gadus morhua. Gen Comp Endocrinol 109:24-36

Eales JG, Brown SB (1993) Measurement and regulation of thyroidal status in teleost fish. Rev Fish Biol Fish 3: 299-347

Eales JG, Shostak S (1985) Free T4 and T3 in relation to total hormone, free hormone indices and protein in plasma of rainbow trout and arctic charr. Gen Comp Endocrinol 58: 291-302

Fostier A, Jalabert B, Billard R, Breton B, Zohar Y (1983) The gonadal steroids. Hoar WS, Randall DJ, Donaldson EM (eds) Fish physiology. Vol. 9A. Academic Press, New York, p $277-372$

Haddy JA, Pankhurst NW (1999) Stress-induced changes in concentrations of plasma sex steroids in black bream. J Fish Biol 55:1304-1316

Halliday RG, Pinhorn AT (1982) The groundfish resource in the Gulf of St. Lawrence. Can Tech Rep Fish Aquat Sci 1086

Hanson JM (1996) Seasonal distribution of juvenile Atlantic cod in the southern Gulf of St. Lawrence. J Fish Biol 49: 1138-1152

Harden Jones FR (1968) Fish migration. St. Martin's Press, New York
Harmin SA, Crim LW, Wiegand MD (1995) Plasma sex steroid profiles and the seasonal reproductive cycle in male and female winter flounder, Pleuronectes americanus. Mar Biol 121:601-610

Hoar WS, Mackinnon D, Redlich A (1952) Effects of some hormones on the behavior of salmon fry. Can J Zool 30: 273-286

Hoar WS, Keenleyside MHA, Goodall RG (1955) The effects of thyroxine and gonadal steroids on the activity of salmon and goldfish. Can J Zool 33:428-439

Hovgård H, Christensen S (1990) Population structure and migration patterns of Atlantic cod (Gadus morhua) in west Greenland waters based on tagging experiments from 1946 to 1964. Northwest Atl Fish Organ Sci Counc Stud $14: 45-50$

Jardine JJ, van-Der-Kraak GJ, Munkittrick KR (1996) Capture and confinement stress in white sucker exposed to bleached kraft pulp mill effluent. Ecotoxicol Environ Saf 33:287-298

Jean Y (1964) Seasonal distribution of cod (Gadus morhua L.) along the Canadian Atlantic coast in relation to water temperature. J Fish Res Board Can 21:429-460

Johnson LL, Casillas EMMS, Rhodes LD, Olson OP (1991) Patterns of oocyte development and related changes in plasma $17 \beta$-estradiol, vitellogenin, and plasma chemistry in English sole Parophyrs vetulus Girard. J Exp Mar Biol Ecol 152:161-185

Lear WH, Green JM (1984) Migration of the 'northern' Atlantic cod and the mechanisms involved. In: McCleave JD, Arnold GP, Dodson JJ and Neill WH (eds) Mechanisms of migration in fishes. Plenum Press, New York, p 309-316

Liley NR, Stacey NE (1983) Hormones, pheromones and reproductive behavior in fish. In: Hoar WS, Randall DJ, Donaldson EM (eds) Fish physiology. Vol. 9B. Academic Press, New York, p 1-63

McKenzie RA (1956) Atlantic cod tagging off the southern Canadian mainland. Bull Fish Res Board Can 105:1-93

Methven DA, Crim LW, Norberg B, Brown JA, Goff GP, Huse I (1992) Seasonal reproduction and plasma levels of sex steroids and vitellogenin in Atlantic halibut (Hippoglossus hippoglossus). Can J Fish Aquat Sci 49:754-759

Moguedet P (1994) Cod (Gadus morhua) migrations in the Gulf of St. Lawrence and areas south of Newfoundland. Northwest Atl Fish Organ Sci Counc Stud 22:71-84

Morehead DT (1998) Effect of capture, confinement and repeated sampling on plasma steroid concentrations and oocyte size in female striped trumpeter Latris lineata (Latrididae). Mar Freshw Res 49:373-377

Omeljianuk RJ, Cook RF, Eales JG (1984) Simultaneous measurement of thyroxine and triiodothyronine in trout plasma using a solid-phase radioimmunoassay. Can J Zool 62:1451-1453

Paloheimo JE, Kohler AC (1968) Analysis of the southern Gulf of St. Lawrence cod population. J Fish Res Board Can 25: 555-578

Pankhurst NW, Dedual M (1994) Effects of capture and recovery on plasma levels of cortisol, lactate and gonadal steroids in a natural population of rainbow trout. J Fish Biol 45:1013-1025

Pickering AD, Pottinger TG, Carragher J, Sumpter JP (1987) The effects of acute and chronic stress on the levels of reproductive hormones in the plasma of mature male brown trout, Salmo trutta L. Gen Comp Endocrinol 68: 249-259

Ponomarenko VP (1996) Distribution of mature cod Gadus morhua of the Barents Sea in relation to seasonal variation in the maturity of gonads. J Ichthyol 36:363-368 
Rose GA (1993) Cod spawning on a migration highway in the north-west Atlantic. Nature 366:458-461

Schwalme K, Chouinard GA (1999) Seasonal dynamics in feeding, organ weights, and reproductive maturation of Atlantic cod (Gadus morhua) in the southern Gulf of St. Lawrence. ICES J Mar Sci 56:303-319

Scott JS (1988) Seasonal spatial distributions of groundfish of the Scotian Shelf and Bay of Fundy, 1974-79 and 1980-84. Can Tech Rep Fish Aquat Sci 1653

Sinclair A, Currie L (1994) Timing of cod migrations into and out of the Gulf of St. Lawrence based on commercial fisheries, 1986-93. DFO Atl Fish Res Doc 94/47

Swain DP (1999) Changes in the distribution of Atlantic cod (Gadus morhua) in the southern Gulf of St Lawrenceeffects of environmental change or change in environmental preferences? Fish Oceanogr 8:1-17

Taggart CT, Penny P, Barrowman N, George C (1995) The 1954-1993 Newfoundland cod-tagging database: statistical summaries and spatial-temporal distributions. Can Tech Rep Fish Aquat Sci 2042

Templeman W (1979) Migration and intermingling of stocks of Atlantic cod, Gadus morhua, of the Newfoundland and

Editorial responsibility: Otto Kinne (Editor), Oldendorf/Luhe, Germany adjacent areas from tagging in 1962-66. Int Comm Northwest Atl Fish Res Bull 14:5-50

Wingfield JC, Grimm AS (1977) Seasonal changes in plasma cortisol, testosterone and oestradiol-17 $\beta$ in the plaice, Pleuronectes platessa L. Gen Comp Endocrinol 31:1-11

Woodhead AD (1959) Variations in the activity of the thyroid gland of the cod, Gadus callarias L., in relation to its migrations in the Barents Sea. J Mar Biol Ass UK 38:407-415

Woodhead PMJ (1970) An effect of thyroxine upon the swimming of cod. J Fish Res Board Can 27:2337-2338

Woodhead AD (1975) Endocrine physiology of fish migration. Oceanogr Mar Biol Annu Rev 13:287-382

Woodhead AD, Woodhead PMJ (1965) Seasonal changes in the physiology of the Barents Sea cod, Gadus morhua L., in relation to its environment. I. Endocrine changes particularity affecting migration and maturation. Int Comm Northwest Atl Fish Spec Publ 6:691-715

Wroblewski JS, Kulka DW, Narayanan S (1995) Winter abundance and movements of northern Atlantic cod (Gadus morhua) along the Newfoundland Labrador continental shelf edge derived from observations on commercial trawlers. Fish Oceanogr 4:128-146

Submitted: June 26, 2000; Accepted: November 22, 2000 Proofs received from author(s): September 24, 2001 